\title{
Pengaruh Strategi Pembelajaran Swa-Atur dengan Discovery Learning dan Gaya Kognitif Terhadap Hasil Belajar Kimia
}

\author{
Moh. Fauzi, Rufi'i, Achmad Noor Fatirul \\ Program Studi Teknologi Pendidikan, Pascasarjana, Universitas PGRI Adi Buana Surabaya
}

\section{Edcomtech}

Jurnal Kajian

Teknologi Pendidikan

Volume 4, No 1, April 2019

56-66

Submitted 03-19-2019

Accepted 05-13-2019

\section{Corresponding Author}

Moh. Fauzi

mohfauzidimdam@gmail.com

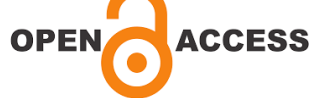

\begin{abstract}
Abstrak
Penelitian ini bertujuan untuk 1) mengetahui perbedaan hasil belajar kimia antara siswa yang mengikuti strategi pembelajaran Swa-Atur dan Discovery Learning,2) mengetahui perbedaan hasil belajar kimia antara gaya kognitif Field Dependence dan gaya kognitif Field Independence, dan 3) untuk mengetahui interaksi antara pembelajaran Swa-Atur, pembelajaran Discovery Learning, dan gaya kognitif siswa terhadap hasil belajar kimia. Penelitian ini merupakan penelitian eksperimen faktorial $2 \times 2$. Kelompok kontrol merupakan kelompok yang mengikuti pembelajaran menggunakan strategi pembelajaran Discovery Learning, sedangkan kelompok eksperimen merupakan kelompok yang mengikuti pembelajaran menggunakan strategi pembelajaran Swa-Atur. Melalui desain analisis ANAVA dua arah ini akan dibandingkan pengaruh strategi pembelajaran Swa-Atur dengan strategi pembelajaran Discovery Learning dan gaya kognitif siswa yaitu Field Dependence dan Field Independence trhadap hasil siswa. Dari analisis diperoleh hasil: Ha.1 diperoleh $F_{\text {hitung }}=22,566$ lebih besar dari $F_{\text {tabel }}$ dengan pembilang 1 dan penyebut 67 yang 3,99 $\left(F_{\text {hitung }}>F_{\text {tabel }}\right)$ dan $p=$ 0,000 maka $p<0,05$ sehingga terbukti bahwa nilai rata-rata kedua populasi tidak sama sehingga terbukti hasil belajar dengan strategi pembelajaran Swa-Atur dan Discovery Learning berbeda secara signifikan pada taraf kepercayaan 95\%. Ha.2 diperoleh $\mathrm{F}_{\text {hitung }}=5,182$ lebih besar dari $\mathrm{F}_{\text {tabel }}$ dengan pembilang 1 dan penyebut 67adalah $3.99\left(F_{\text {hitung }}>F_{\text {tabel }}\right)$ dan $p=0,000$ maka $p<0,05$ berarti bahwa hasil belajar siswa yang memiliki gaya kognitif Field Independence dan gaya kognitif Field Dependence berbeda secara signifikan pada taraf kepercayaan 95\%, dan Ha.3 diperoleh $F_{\text {hitung }}=0,219$ lebih kecil dari $F_{\text {tabel }}$ dengan pembilang 1 dan penyebut 67adalah $3.88\left(F_{\text {hitung }}<F_{\text {tabel }}\right)$ dan $p=0,641$ maka $p>0,05$ berarti bahwa tidak ada interaksi strategi pembelajaran Swa-Atur dan Discovery Learning dan gaya kognitif siswa terhadap hasil belajar pada taraf kepercayaan 95\%. Kesimpulan yang diperoleh bahwa siswa yang diberi strategi pembelajaran SwaAtur menunjukkan hasil belajar lebih tinggi dari strategi pembelajaran Discovery Learning. Siswa yng mempunyai Field Independence ia dapat mempunyai waktu lebih banyak dari yang memiliki Field Dependence. tidak adanya hubungan belajar dengan hasil belajar kimia.
\end{abstract}

Kata kunci: Swa-Atur, Discovery Learning, Gaya Kognitif, Hasil Belajar. 


\section{LATAR BELAKANG}

Pembelajaran yang umumnya diterapkan disekolah, peneliti merasa hasil belajar siswa masih bias dinaikkan dengan pembelajaran yang dapat melatih siswa untuk mampu belajar mandiri dan melibatkan siswa berproses secara aktif dalam pembelajaran. Karena pembelajaran mandiri mampu melibatkan siswa untuk aktif mengambil kendali serta tanggungan belajar mereka, serta menggunakan berbagai strategi untuk mencapai tujuan belajar. Pembelajaran yang sesuai untuk permasalahan tersebut adalah dengan menerapkan pembelajaran Swa-Atur (Self-Regulated). Penelitian ini mengangkat permasalahan 1) apakah muncul perbedaan yang mendasar dari siswa yang menggunakan strategi pembelajaran SwaAtur dan Discovery Learning pada SMA 2 Negeri bangkalan dan 4 Bangkalan, 2) apakah muncul perbedaan hasil belajar siswa yang pakai gaya kognitif Field Dependence dan gaya kognitif Field Independence di SMA 2 dan 4 Negeri Bangkalan, dan 3) apakah muncul strategi belajar siswa Swa-Atur, pembelajaran Discovery Learning, dan gaya kognitif siswa terhadap hasil belajar siswa kimia di SMA Negeri 2 dan 4 Bangkalan?

Tujuan peneliti utk tau perbedaan hasil belajar kimia antara siswa yang mengikuti strategi pembelajaran Swa-Atur dan Discovery Learning, mengetahui perbedaan hasil belajar kimia antara siswa yang punya gaya kognitif Field Dependence dan gaya kognitif Field Independence, dan untuk Untuk mengetahui interaksi antara pembelajaran Swa-Atur, pembelajaran Discovery Learning, dan gaya kognitif trhadap hasil beljar siswa kimia.

Self regulation ada dua kata yang membentuk, self yang artinya diri dan regulation artinya pengaturan. Self regulation dapat diartikan pengaturan diri. "Students can be described as self-regulated to the degree that they are metacognitively, motivationally, and behaviorally active participants in their own learning process" (Zimmerman, 1989). Self-regulated siswa bisa digambarkan melalui tingkat metakognisi, semangat tingkah laku mereka yang berpartisipasi secara aktif dalam proses belajar. Siswa yang mampu untuk mengarahkan belajarnya, merencanakan mengorganisasikan, mengevaluasi belajarnya saat mencari data maka siswa tersebut melakukan proses metakognisi (Zimmerman, 1989)..

Zumburnn et al (2011) mengatakan bahwa "self-regulated learning is a process that assists students in managing their thoughts, behaviors, and emotions in order to successfully navigate their learning experiences". Self regulated learning merupakan proses mengatur diri siswa terhadap pikiran, perilaku dan emosi agar berhasil menunjukkan pengetahuan mereka. Pintrich dalam Mezei (2008) mengatakan bahwa: "Self-regulated learning is an active, constructive process whereby learners set goals fortheir learning and then attempt to monitor, regulate, and control their cognition, motivation, and behavior, guided and constrained by their goals". Pembelajaran Swa-Atur merupkan proses aktif, konstruktif, dimana siswa menentukan tujuan belajar mereka, memantau, mengatur serta memantau kognisi, semangat dan tingkah laku yang dibimbing dan dibatasi tujuan mereka. Sedangkan Santrock (2010) mengatakan bahwa pembelajaran regulasi diri terdiri dari penciptaan pikiran, perasaan dan perilaku sendiri dalam mencapai suatu tujuan belajar. Pembelajaran Swa-Atur pada dasarnya adalah suatu pembelajaran mandiri yang mengatur pikir, rasa, dan lakuan sendiri. Pembelajaran Swa-Atur merupakan proses aktif mengambil tanggung jawab terhadap belajar mereka (siswa) melalui penerapan berbagai strategi untuk membantu dalam belajar mereka (Arabzadeh et al, 2012).

Pembelajaran Swa-Atur berasal dari teori kognisi sosial Bandura. Teori sosial kognitif menyebutkan factor sosial, kognitif serta perilaku, mempunyai peran dalam proses pembelajaran. Teori kognisi sosial Bandura menyatakan bahwa didalam pembelajaran terdapat tiga faktor yang berperan penting yaitu faktor person dan kognisi, sosial atau lingkungan, dan perilaku (Santrock, 2010). Tiga faktor tersebut bagai sebab akibat atau saling mempengaruhi. Seseorang mengordinasi diri sendiri (Self Regulated) yang hasilnya 
berupa perilaku. Perilaku yang dilakukan akan berdampak pada lingkungan dan demikian seterusnya.

Keadaan diri, lingkungan masyarakat siswa punya peran Self Regulated Learning semula berkembang trhadap pengaruh social ke diri sendiri (siswa mengambil tanggung jawab terhadap belajarnya). Menurut Ellis (2008) seiring waktu anak-anak/siswa akan mengambil alih tanggung jawabnya dengan menentukan tujuan belajar mereka sendiri, fokus terhadap tugas, mengidentifikasi strategi-strategi yang efektif dan mengevaluasi pembelajaran mereka sendiri. Ellis menjelaskan lebih lanjut bahwa alat hubung pembelajaran yang diatur orang lain (Other Regulated Learning) dan pembelajaran yang diatur sendiri (Self Regulated learning) merupakan belajar secara bersama (CoRegulated Learning). Hal ini dapat dilakukan dengan siswa/guru/Bersama keduanya menentukan tujuan yang spesifik dari suatu usaha belajar atau guru memberikan kriteria belajar yang sukses dan minta ke siswa mengevaluasi belajarnya berdasarkan kriteria tersebut.

Schunk (2005) menyatakan bahwa pembelajaran Swa-Atur dapat berlangsung jika siswa dapat secara sistematik mengarahkan perilaku dan kognisi dengan memberi perhatian trhdap petunjuk tugas, sinambungan proses dan pengetahuan, informasi diulang dan dikembangkan serta meyakini kemampuan belajar yang positif (Self Efficacy) serta pandai memprediksi belajarnya. Chatzistamatiou \& Dermitzak (2013) menyatakan bahwa "the process of self-regulated learning follows three cyclical phases, that is, forethought, performance or volitional control, and self-reflection".
Hal tersebut mengacu pada tiga fase siklus yang diterapkan oleh Zimmerman (1989). Pemikiran, pemantauan kinerja, dan refleksi terhadap kinerja, merupakan siklus dari Self Regulated Learning. Terdapat sedikit perbedaan dengan fase Self Regulated Learning Pintrich yang dinyatakan oleh Schunk (2005) bahwa "there are four phases of self regulation forethought, planning, and activation, monitoring, control, reaction and reflection". Self regulated learning mempunyai empat fase yaitu perencanaan, pemikiran dan aktivasi; pemantauan; kontrol serta reaksi dan refleksi. Zumburnn et al (2011) menyatakan bahwa "cyclical model of self regulated learning discusses three distinct phases: forethought and planning, performance monitoring, and reflections on performance". Terdapat tiga fase self regulated learning yaitu pemikiran dan perencanaan, pemantauan kinerja dan refleksi kinerja. Tiga fase yang diungkapkan oleh Zumburnn merupakan gabungan dari fase yang diungkapkan oleh Zimmerman dan Pintrich.

Pelajar mandiri dapat menetapkan tujuan Panjang/pendek jangkanya untuk pembelajaran mereka, merencanakan ke depan untuk mencapai tujuan mereka, memotivasi diri, dan focus pada tujuan dan kemajuan mereka. Mereka juga mampu menggunakan beberapa strategi belajar dan menyesuaikan strategi-strategi yang diperlukan, memantau diri perkembangan mereka, mencari bantuan dari orang lain yang diperlukan, dan mengevaluasi belajar serta kemajuan berdasarkan hasil belajar mereka. Tahapan pembelajaran dengan strategi Self Regulated learning menurut Zumburnn et al (2011) sebagai berikut.

Tabel 1. Strategi Self Regulated Learning

\begin{tabular}{llll}
\hline $\begin{array}{c}\text { Strategi Self } \text { Regulated } \\
\text { Learning }\end{array}$ & \multicolumn{1}{c}{ Aktivitas Guru } & \multicolumn{2}{c}{ Aktivitas Siswa } \\
\hline Menetapkan tujuan & $\begin{array}{l}\text { Meminta siswa untuk menuliskan tujuan } \\
\text { yang ingin dicapai dalam belajar. }\end{array}$ & $\begin{array}{l}\text { Menuliskan } \\
\text { dicapai. }\end{array}$ & tujuan yang ingin \\
\hline Perencanaan & Memberikan saran sumber-sumber belajar & $\begin{array}{l}\text { Mempersiapkan } \\
\text { yang dapat digunakan. }\end{array}$ & sumber-sumber \\
& belajar yang akan digunakan. \\
\hline
\end{tabular}




\begin{tabular}{|c|c|c|}
\hline $\begin{array}{l}\text { Strategi Self Regulated } \\
\text { Learning }\end{array}$ & Aktivitas Guru & Aktivitas Siswa \\
\hline & $\begin{array}{l}\text { Menyajikan informasi melalui demostrasi } \\
\text { atau bacaan. }\end{array}$ & Memperhatikan penjelasan guru. \\
\hline & Membagi siswa dalam kelompok belajar. & Mengikuti arahan guru. \\
\hline $\begin{array}{l}\text { Penggunaan strategi } \\
\text { yang fleksibel }\end{array}$ & $\begin{array}{l}\text { Memberikan saran kepada siswa untuk } \\
\text { mencatat informasi penting yang diperoleh, } \\
\text { memberitanda informasi penting yang ada } \\
\text { dibuku. }\end{array}$ & $\begin{array}{l}\text { Memilih dan melakukan saran guru } \\
\text { yang sesuai. }\end{array}$ \\
\hline Motivasi diri & $\begin{array}{l}\text { Meminta siswa untuk menggunakan } \\
\text { sumber belajar yang telah di pilih. }\end{array}$ & $\begin{array}{l}\text { Menggunakan sumber belajar yang } \\
\text { telah di pilih. }\end{array}$ \\
\hline Pemantauan diri & $\begin{array}{l}\text { Meminta siswa untuk melihat dan } \\
\text { memeriksa tugas yang dikerjakan sudah } \\
\text { tepat. }\end{array}$ & $\begin{array}{l}\text { Memeriksa kembali tugas yang telah } \\
\text { dikerjakan apakah sudah tepat. }\end{array}$ \\
\hline Kontrol atensi & $\begin{array}{l}\text { Memberikan waktu siswa untuk istirahat } \\
\text { atau rilek }\end{array}$ & Mengukuti intruksi guru \\
\hline Mencari Bantuan & $\begin{array}{l}\text { Memberikan saran kepada siswa jika } \\
\text { mengalami kesulitan dapat melihat buku } \\
\text { paket, bertanya kepada teman maupun } \\
\text { mencari di internet. }\end{array}$ & $\begin{array}{l}\text { Mencari bantuan melalui buku } \\
\text { paket, bertanya kepada teman } \\
\text { maupun mencari diinternet. }\end{array}$ \\
\hline \multirow[t]{3}{*}{ Evaluasi diri } & $\begin{array}{l}\text { Meminta siswa untuk memeriksa kembali } \\
\text { pekerjaan yang telah dikerjakan. }\end{array}$ & $\begin{array}{l}\text { Memeriksa kembali pekerjaan yang } \\
\text { telah dikerjakan. }\end{array}$ \\
\hline & $\begin{array}{l}\text { Memberikan soal kepada siswa untuk } \\
\text { dikerjakan. }\end{array}$ & $\begin{array}{l}\text { Mengerjakan soal yang diberikan } \\
\text { guru. }\end{array}$ \\
\hline & Memberikan reward. & Memperhatikan penjelasan guru. \\
\hline
\end{tabular}

Metode penemuan (Discovery) berarti pengajaran, personal, pengganti objek serta test merupakan prosedur penting dalam mengajar sebelum sampai proses keseluruhan, Sehingga metode ini (Discovery) melingkupi cara mengajar aktif, mengacu proses, mendiri, serta refleksi dalam cara mengajar (Suryosubroto, 2009). Menurut Hanafiah (2009) Discovery melibatkan kemampuan siswa dlm pembelajaran yang digunakan secara teratur, kritis, masuk akal jadi siswa bisa kreatif dalam pengetahuan, sikap, serta perubahan kebiasaan. Richard dalam Suryosubroto (2009) menerapkan Self-Learning siswa mendiri, implikasi yang dihasilkan adalah situasi belajar mengajar dari situasi teacher dominate learning menjadi situasi student dominated learning. Discovery Learning menciptakan cara mengajar membentuk mental siswa dengan interaktif, diskusi, pertemuan, aktif membaca, serta mengaplikasikan cara tersebut dengan mandiri. Model Discovery Learning berawal dari siswa sebagai subjek/objek belajar, sehingga mampu mengoptimalkan kemampuan diri. Cara ini dipandang sebagai motivasi guna merangsang siswa lebih giat dalam proses belajar.

Model Discovery-Inquiry atau Discovery Learning menurut Suryosubroto (2009) proses pengajaran serta trik sebagai prosedur penting mengajar sebelum proses keseluruhan. Discovery merupakan penyerapan konsep dan prinsip dalam membentuk mental siswa. Mengamati, menggolongkan, menduga, menjelaskan, mengukur, menyimpulkan, inilah proses mental siswa. Discovery Learning sebagai siasat pembelajaran, mengutamakan pandangan/paham yang belum diketahui. Discovery Learning menyodorkan 
permasalahan yang telah disetting oleh guru kepada siswa. Bruner (dalam Arends, 2008) berpendapat bahwa Discovery Learning ditujukan untuk memahami tatanan/ kunci ide suatu ilmu, melibatkan siswa dalam pembelajaran, serta meyakini Personal Discovery (penemuan pribadi) merupakan pembelajaran sesungguhnya/sejati. Suprijono (2010) berpendapat Discovery Learning pemfokusan masalah sesuai dengan konteks. Informasi, memodifikasi, dan menilai merupakan bentuk proses belajar. Siswa dapat menerima informasi tentang materi yang dipelajari. Siswa utuk mmperoleh informasi dapat malakukan pengkodean terhadap info yang diterima. Respon tersebut dilakukan siswa atas informasi yng didpat. Ada pula mereka menganggap sesuatu yang baru. Penyikapan mendalam dilakukan terhadap informasi yang didapt serta perluasan pengetahuan yang mereka miliki.

Transformasi berarti melakukan pengenalan, analisis, perubahan, memodifikasi informasi yng diproleh siswa mnjadi bntuk yang abstrak dan ideal bertujuan bisa dimanfaatkan lebih luas. Deduksi logika siswa dikembangkan, tahap inilah dirasa sulit bagi para peneliti. Guru dituntut untuk aktif menyampaikan strategi psikologis yng tpat. Evaluasi merupkan tahap dimana siswa menilai sendiri informasi yng dismpaikan sehingga mereka dapat memanfaatkan guna untk paham tentang permasalahan yang dihadapi. Kemendikbud berpendapat (dalam materi pelatihan guru implementasi kurikulum 2013), Discovery Learning sebuah teori belajar untuk siswa dalam pembelajaran bilamana mereka tidak disajikan materi belajar dengan system final, sehingga harapan kita mereka dapat menata diri sendiri. Simpulan yng dpat peneliti sampaikan dari pendapat di atas, Discovery Learning sebuah pemecahan masalah sebagai proses pembelajaran, hal tersebut menuntut siswa mengeksplor informasi yng di dpat untuk membentuk mental dengan arahan guru yang disampaikan melalui pertanyaan tentang tujuan pembelajaran. Discovery Learning merupakan pembelajaran berdasarkan penemuan (Inquiry-Based), bentuk serta teori bagaimana cara belajar.
Jalan cerita dalam pembelajaran dilakukan pada siswa buat menyelesaikan maslah yng dihadapi dengan kemampuan mereka sendiri. Para siswa menggunakan pengalaman mereka untk mencari solusi atas masalah yng merka hadapi. Mereka manggali, bereksperimen dan berinteraksi terhadap Teknik trial and eror. Alma (2010) berpendapat bahwa Model pembelajaran Discovery Learning dapat pula disebut pendekatan inkuiri berdasarkan pada keyakinan tentang perkembangan murid secara mandiri. Perlu penelitian ilmiah secara aktif terhadap model ini. Pendapat ini juga didukung oleh pernyataan bahwa anak itu harus aktif berperan serta dalam prosen belajar di kelas.

Psikologi dimiliki oleh individu, dalam memproses informasi serta mengelompokkan kagiatan setiap orang berbeda. Perbedaan kualitas serta kuantitas hasil kegiatan belajar siswa juga dipengaruhi psikologi seseorang. Gaya kognitif (Cognitive Style) sebutan dari Perbedaan ini. Gaya kognitif merupakan cara memperoleh informasi serta merespon stimuli lingkungan skitar menggunakan sebuah strategi. Menurut Woolfolk (1993), gaya kognitif adalah melihat, mengenal, megelompokkan informasi dengan cara yang berbeda oleh tiap siswa. Woolfolk (1993) menjelaskan lebih lanjut bahwa cepat/ lambatnya kemampuan merespon tergantung pada sikap dan kualitas tiap individu. Gaya kognitif terlihat dalam variasi individu ketika memperhatikan, mengingat, menunjukkan informasi, serta pikiran berbeda yng ditunjukkan dari kognisi serta kepribadian. Gaya kognitif juga dapat dibentuk ketika mereka memproses informasi, hal tersebut bersifat normal, tetapi tetep dapat berubah.

Riding and Rayner (1998) menjelaskan gaya kognitif merupakan pendekatan dalam bentuk pengelompokan serta gambaran informasi secara konsisten. Dimensi psikologi merupakan gaya kognitif tentang kerakter seorang untuk merespon segala informasi yng ditrima. Gaya kognitif merupakan perolehan, pengelompokkan, pengambaran dan proses informasi yang dilakukan individu secara konsisten. Keefe (1987) menjelaskan luas tentang gaya kognitif yang merupakan penggambaran perilaku kebiasaan dalam 
menerima, berpikir, mencari solusi permasalahan, serta mengingat informasi sebagai gaya belajar seseornag. Messick dalam tulisan Anastasi \& Urbina (1997) menytakan hal yg sama, dia berpendapat gaya kognitif merupakan cara khas seseorang utuk memahami, berpikir, mengingat, serta mencari solusi permasalahan. Gaya kognitif menurut Woolfolk (1993) itu dibedakan manjadi dua macam, yaitu aspek psikologi yang berbeda merupkan aspek pertama terdiri atas Field Dependence dan Field Independence, Waktu pemahaman konsep merupakan aspek kedua yang terdiri atas gaya impulsif dan reflektif. Salah satu variable yang digunakan dalam penelitian ini berbentuk gaya kognitif Field Dependence dan Field Independence.

Kesimpulan yang dapat dikatakan bahwa Gaya kognitif merupakan Teknik yang disukai oleh individu berkaitan dengan menerima, memproses info, dan mencari solusi guna memecahkan permasalahan dengan relative tetap. Individu yang tidak terpengaruh situasi lingkungan dan social sehingga mereka mandiri, kategori yang tepat buat mereka ialah Field Independence. Sebaliknya jika individu tersebut selalu mengantungkan kondisi mereka terhadap lingkungan dan keadaan social masyarakat ketegori yang tepat buat mereka adalah kategori Field Dependence.
Instrument/alat dibutuhkan guna mengukur/menetapkan gaya kognitif siswa. Instrument yang dibutuhkan ada berbagai macam diantaranya yang dikembangkan para pakar seperti GEFT (Group Embedded Figuree Test), MFFT (Matchiing Familliar Figure Test), RFT (Rod and Frame Test), serta profil gaya kognitif sebagai perangkat tes yang dikembangkan oleh NASSP (national association of Secondarry schoo I Pricipals).

Siswa yang bergaya kognitif Field Dependence dapat dipahami pengaruh lingkungan sangat besar dan utama bagi mereka. Pola berpikir mereka global (mereka berpikir dengan menyeluruh), pemikiran analitik dan teratur/sistematik tidak terlalu dibutuhkan untuk siswa yang berpikiran seperti ini. Ilmu social, sangat diminati untuk siswa yang memiliki tipe gaya berpikir seperti ini. Hubungan social yang dilakukan karakter ini (Field Dependence) cenderung dapat menerima berbagai masukan/kritikan baik itu dilakukan teman maupun guru. Tahap pemecahan masalah terdapat kesulitan untuk siswa bergaya kognitif Field Dependence, oleh karena itu mereka membutuhkan bantuan, dorongan/motivasi dari teman dekat, atau dari guru guna meningkatkan kepercayaannya. Berikut ini perbedaan gaya kogniitif Field I/ndependence dan Field Dependence:

Tabel 2. Perbedaan Gaya Kognitif Field Independence dan Field Dependence

\section{Field Independeence}

1. Berorientasi impersonal perorangan).

2. Kemampuan memecahkan masalah

3. Mengutamakan dorongan dari internal untuk beraktivitas ataubelajar

4. memilih ketika menjalin hubungan emosional terhadap orang lain

5. Siswa selalu berusaha bekerja sendiri serta senang mencoba hal terbaru tanpa menerima bantuan siapapun/guru

\section{Field Dependeence}

1. Berorientasi sosial ataulingkungan

2. Bimbingan dibutuhkan guna memecahkan permasalahan

3. Mengutamakan motivasi eksternal dalam beraktivitas ataubelajar

4. Mudah/supel dalam menjalin hubungan emosional dengan oranglain

5. Siswa cenderung menerima pendapatataupertimbangandari teman atauguru 


\section{METODE PENELITIAN}

Rancangan penelitian adalah suatu desain atau program penelitian yang merupakan tahapan proses yang diperlukan untuk merencanakan dan melaksanakan penelitian. Pendekatan yng digunakn adalah pendekatan Kuantitatif dimana data yang dikumpulkan berupa angka (statistik). Penelitian ini merupakan penelitian eksperimen faktorial $2 \times 2$. Sebuah penelitian eksperimen minimal menikutkan 2 kelompok; kelompok kontrol dan kelompok eksperimen. Kelompok kontrol merupakan kelompok yang mengikuti pembelajaran menggunakan strategi pembelajaran Discovery Learning, sedangkan kelompok eksperimen merupakan kelompok yang mengikuti pembelajaran menggunakan strategi pembelajaran Swa-Atur. Melalui desain ini akan dibandingkan pengaruh pembelajaran Swa-atur dan pembelajaran Discovery Learning dangan gaya kognitif siswa yaitu Field Dependeence dan Field Independece terhadap hasil belajar kimia. Desain factorial tersebut terdapat pada tabel berikut.

Tabel 3. Desain Faktorial $2 \times 2$

\begin{tabular}{lcc}
\hline \multirow{2}{*}{ Gaya Kognitif $(\mathrm{A})$} & \multicolumn{2}{c}{ Model pembelajaran $(\mathrm{X})$} \\
\cline { 2 - 3 } & Swa-atur $\left(\mathbf{X}_{\mathbf{1}}\right)$ & Discovery Learning $\left(\mathbf{X}_{\mathbf{2}}\right)$ \\
\hline Field Dependence $\left(\mathrm{A}_{1}\right)$ & $\mathrm{Y}_{11}$ & $\mathrm{Y}_{12}$ \\
\hline Field Independence $\left(\mathrm{A}_{2}\right)$ & $\mathrm{Y}_{21}$ & $\mathrm{Y}_{22}$ \\
\hline
\end{tabular}

Deskripsi populasi yang peneliti ambil adalah siswa kelas X SMA Negeri 2 dan 4 Bangkalan dalam bidang mata ajar kimia. Sedangkan sampel yang diambil berjumlah 71 responden siswa. Dengan teknik acak dlam mengambil sample (random sampling). Analisis dilakukan dengan ANAVA dua jalur menggunakan SPSS.

\section{HASIL PENELITIAN}

Berdasarkan variabel-variabel dalam penelitian ini, ada dua variabel bebas yaitu pembelajaran Swa-atur, Discovery Learning, gaya kognitif dan variabel terikatnya merupakn hasil belajar. Data hasil penelitian dapat dikelompokkan seperti berikut :

\section{Descriptive Statistics}

Dependent Variable: Hasil Belajar

\begin{tabular}{llcrr}
\hline Strategi & Gaya Kognitif & Mean & Std. Deviation & \multicolumn{1}{c}{$\mathrm{N}$} \\
\hline Swa-Atur & FD & 29,7857 & 4,8545 & 14 \\
& FI & 31,7727 & 3,9028 & 22 \\
& Total & 31,0000 & 4,3425 & 36 \\
\hline Discovery Learning & FD & 24,0500 & 5,6706 & 20 \\
& FI & 27,0667 & 3,2616 & 15 \\
& Total & 25,3400 & 4,4965 & 35 \\
\hline Total & FD & 26,4118 & 6,0006 & 34 \\
& FI & 29,8649 & 4,3022 & 37 \\
& Total & 28,21 & 5,432 & 71 \\
\hline
\end{tabular}

Dari tabel dapat diketahui bahwa siswa dengan strategi pembelajaran Swa-Atur memiliki nilai rata-rata lebih dibandingkan siswa dengan strategi pembelajaran Discovery Learning.

Untuk mendapatkan gambaran awal mengenai hasil belajar siswa yang memiliki
GK-FD dengan siswa yang memiliki GK-FI, maka perlu dibandingkan antara nilai ratarata keduanya. Dengan membandingkan akan dapat diketahui bahwa ada atau tidak perbedaan nyata antara siswa yang memiliki GK-FD dan GK-FI. Adapun perbandingan nilai tersebut terdapat pada tabel berikut. 
Tabel 5. Perbedaan nilai rata-rata hasil belajar siswa dengan GK-FD dan GK-FI

\begin{tabular}{ccc}
\hline No & Straegi & Nilai Rata-rata \\
\hline 1 & Siswa dengan GK-FD & 26,4118 \\
\hline 2 & Siswa dengan GK-FI & 29,8649 \\
\hline
\end{tabular}

Dari tabel dapat diketahui siswa yang berGK-FD memiliki nilai rata-rata kimia lebih kecil dari siswa yang memiliki GK-FI. Dari penelitian ini jelas siswa yang mempnyai GK-FI adalah modal kondisi yang berperan penting dalam mencapai hasil belajar yng lbih baik. Oleh sebab itu, dalam pembelajaran sangat penting memberikan pengarahan, nasehat dan berbagai usaha meningkatkan semangat/ motivasi belajar untuk mencapai prestasi yang lebih gemilang. Setelah dilaksanakan uji normalitas dan homogenitas varian baik yang diproleh dari angket dan tes terbukti telah menunjukkan bahwa data hasil belajar berdistribusi normal dan varians data belajar siswa dengan strategi pembelajaran Swaatur dan Discovery Learning telah terbukti homogen, selanjutnya dilakukan uji hipotesis. Hipotesis yang dihasilkan dari penelitian ini ada 3 yaitu. Hipotesis pertama (Ha.1) untuk mengetahui perbedaan siswa tentang hasil belajar dalam mendapatkan pembelajaran kimia dalam strategi pembelajaran Swaatur dengan siswa yang mendapatkan pembelajaran kimia dengan strategi pembelajaran Discovery Learning, hipotesis kedua (Ha.2) untuk mengetahui terdapat perbedaan hasil belajar antara siswa yang mememiliki gaya kognitif Field Independence dengan siswa yang memiliki gaya kognitif Field Dependence dalam pembelajaran kimia. Sedangkan hipotesis ketiga (Ha.3) untuk mengetahui ada atau tidaknya interaksi antara strategi pembelajaran Swa-Atur, strategi pembelajaran Discovery Learning, dan gaya kognitif. Yang dilakukan untuk hasil belajar pelajaran kimia kelas $x$ diuji dengan ANOVA dua jalan dengan menggunakan bantuan program SPSS 12 for windows. Adapun hasil perhitungan sebagai berikut:

\section{Tests of Between-Subjects Effects}

Dependent Variable: Hasil Belajar

\begin{tabular}{lrrrrr}
\hline Source & $\begin{array}{c}\text { Type III Sum } \\
\text { of Squares }\end{array}$ & df & Mean Square & \multicolumn{1}{c}{ F } & Sig. \\
\hline Corrected Model & $679,72^{7}$ & 3 & 226,576 & 10,952 &, 000 \\
Intercept & 54359,631 & 1 & 54359,631 & 2627,577 &, 000 \\
Strategi & 466,841 & 1 & 466,841 & 22,566 &, 000 \\
GK & 107,201 & 1 & 107,201 & 5,182 &, 026 \\
Strategi * GK & 4,539 & 1 & 4,539 &, 219 &, 641 \\
Error & 1386,104 & 67 & 20,688 & & \\
Total & 58573,000 & 71 & & & \\
Corrected Total & 2065,831 & 70 & & & \\
\hline
\end{tabular}

a. R Squared $=, 329$ (Adjusted R Squared $=, 299$ )

Dari tabel faktor antar subyek diketahui bahwa jumlah responden yang dianalisis, untuk strategi pembelajaran Swa-Atur berjumlah 36, strategi pembelajaran Discovery Learning 35, gaya kognitf Field Dependence berjumlah 34, dan Gaya Kognitif Field
Indepedence berjumlah 37. Jadi keseluruhan berjumlah 71. Dari tabel hasil uji ANOVA dua jalan dapat diambil 3 keputusan.

Perbedaan yang nyata dapat diketahui dengan melihat, hasil belajar strategi Pembelajaran Swa-atur dan Discovery 
Learning, perlu diketahui dasar pengambilan keputusan sebagai berikut : apabila probabilitas $(p)>0,05$ maka Ho diterima artinya kedua rata-rata populasi tidak berbeda, sedangkan bila $(p)<0,05$, maka $\mathrm{Ho}$ ditolak dan $\mathrm{Ha}$ diterima artinya nilai rata-rata kedua populasi berbeda nyata. Oleh karena $F_{\text {hitung }} 22,566$ lebih besar dari $F_{\text {tabel }}$ dengan dk pembilang 1 dan penyebut 67 yaitu 3,99 $\left(F_{\text {hitung }}>F_{\text {tabel }}\right)$ dan $p=0,000$ maka $p<0,05$ artinya nilai rata-rata kedua populasi tidak sama sehingga terbukti bahwa hasil belajar strategi pembelajaran Swa-Atur dan Discovery Learning berbeda secara jelas/signifikan pada taraf kepercayaan $95 \%$.

Untuk mengetahui ada tidaknya perbedaan yang nyata, hasil belajar siswa yang memilikki gaya kognitif Field Independence dan gaya kognitif Dependence, perlu diketahui dasar pengambilan keputusan sebagai berikut : apabila probabilitas $(p)>0,05$ maka Ho diterima artinya kedua rata-rata populasi tidak berbeda, sedangkan bila $(p)<0,05$, maka Ho ditolak dan Ha diterima artinya nilai rata-rata kedua populasi berbeda nyata. Oleh karena $F_{\text {hitung }} 5,182$ lebih besar dari $F_{\text {tabel }}$ dengan $d k$ pembilang 1 dan penyebut 67 yaitu 3,99 $\left(F_{\text {hitung }}>F_{\text {tabel }}\right)$ dan $p=0,000$ maka $p<0,05$ artinya nilai rata-rata kedua populasi tidak sama sehingga terbukti bahwa siswa yang memiliki gaya kognitif Field Independence dan gaya kognitif Field Dependence meiliki hasil belajar yang berbeda, jelas perbedaan tersebut pada taraf kepercayaan $95 \%$.

Hipotesis ketiga (Ha.3) : terdapat interaksi antara strategi pembelajaran dan gaya kognitif siswa terhadap hasil belajar. Untuk mengetahui ada tidaknya interaksi antara hasil belajar dan gaya kognitif siswa kelas $\mathrm{x}$ strategi pembelajaran Swa-Atur dan Discovery Learning pada mata pelajaran kimia kelas x di SMA Negeri 2 dan 4 Bangkalan, perlu diketahui dasar pengambilan keputusan sebagai berikut : apabila probabilitas $(p)>0,05$ maka Ho diterima artinya tidak ada interaksi, sedangkan bila $(p)<0,05$, maka Ho diterima dan $\mathrm{Ha}$ ditolak artinya tidak ada interaksi strategi pembelajaran kimia dan gaya kognitif siswa terhadap hasil belajar.

Oleh karena $F_{\text {hitung }}$ 0,219 lebih kecil dari
$\mathrm{F}_{\text {tabel }}$ dengan $\mathrm{dk}$ pembilang 1 dan penyebut 67 yaitu 3,88 $\left(F_{\text {nitung }}<F\right.$ tabel $)$ dan $p=0,641$ maka $p>0,05$ artinya tidak ada interaksi strategi pembelajaran Swa-atur dan Discovery Learning dan gaya kognitif siswa terhadap hasil belajar pada taraf kepercayaan $95 \%$.

\section{PEMBAHASAN}

Berdasarkan hasil pengujian diperoleh bahwa pembelajaran Swa-Atur lebih unggul untuk meningkatkan hasil belajar kimia dibandingkan dengan pembelajaran Discovery Learning. Dalam hal ini, diperoleh bahwa kelompok siswa yang pembelajaran swa-atur memperoleh hasil belajar kimia yang berbeda dibandingkan dengan kelompok siswa yang mengikuti pembelajaran Discovery Learning. Hasil rata-rata dari belajar siswa Swa-Atur yaitu sebesar 31, sedangkan pembelajaran Discovery Learning memiliki rata-rata hasil belajar sebesar 25,34.

Berdasarkan hasil perhitungan dengan anova yang ditunjukkan pada baris kelompok $\mathrm{F}_{\text {hit }}=22,566$ pada taraf signifikansi $5 \%$ diperoleh $F_{\text {tabel }}=3$,99. Jadi $F_{\text {hit }}>F_{\text {tabel }}$ atau dapat juga dilihat dari nilai signifikansinya yaitu nilai signifikan pada kolom sig.menunjukan angka 0,000 , hal ini lebih kecil dari angka 0,05; berarti terbukti bahwa hasil belajar pembelajaran Swa-Atur dan pembelajaran Discovery Learning secara signifikan berbeda pada taraf kepercayaan 95\%.

Sesuai dengan hipotesis yang diujikan dalam penelitian ini, adanya perbedaan hasil belajar kimia yang diperoleh siswa yang mengikuti pembelajaran Swa-Atur dibanding kelompok siswa yang mengikuti pembelajaran Discovery Learning, telah diprediksi sebelumnya. Hal ini dapat diprediksi karena berdasarkan teori-teori yang kaidah penelitian ini, pembelajaran Swa-Atur memiliki potensi yang baik untuk meningkatkan hasil belajar kimia dibandingkan dengan pembelajaran Discovery Learning. Dengan hal ini, dengan pembelajaran Swa-Atur, siswa akan semakin aktif belajar.

Hasil penelitian ini seperti yang telah dikemukakan di muka menunjukkan bahwa kelompok siswa yang memiliki gaya kognitif Field Depedence memperoleh hasil belajar 
yang berbeda dibanding kelompok siswa yang memiliki gaya kognitif Filed Independence. Hasil penelitian ini juga telah diprediksi sebelumnya. Hal ini dapat diprekdiksi karena gaya kognitif Filed Independence memiliki potensi untuk memberi pengaruh terhadap hasil belajar siswa, dan dapat dilihat dari rata-rata hasil belajar siswa yang mempunyai gaya kognitif Field Dependence sebesar 26,4118 , sedangkan hasil belajar siswa yang mempunyai gaya kognitif Filed Independence mempunyai rata-rata sebesar 29,8649. Berdasarkan hasil perhitungan dengan anova yang ditunjukkan pada baris kelompok $\mathrm{F}_{\text {hit }}=$ 5,182 pada taraf signifikansi $5 \%$ diperoleh $F_{\text {tabel }}$ $=3,99$. Jadi $F_{\text {hit }}>F_{\text {tabel }}$ atau dapat juga dilihat dari nilai signifikansinya yaitu nilai signifikan pada kolom sig.menunjukan angka 0,026, hal ini lebih kecil dari angka 0,05; berarti terbukti bahwa siswa yang memiliki gaya kognitif Field Dependence dan gaya kognitif Field Independence hasil belajar yng berbeda secara signifikan/jelas pada taraf kepercayaan 95\%.

Hasil pengujian hipotesis dalam penelitian ini menunjukkan bahwa interaksi antara strategi pembelajaran dengan gaya kognitif yng terhadap hasil belajar kimia tidak ada. strategipembelajaran menurut hasil penelitian menyatakan Swa-Atur dan Discovery Learning memberi pengaruh yang berbeda terhadap hasil belajar lepas dan tinggi rendahnya gaya kognitif Field Dependence siswa. Sebaliknya, gaya kognitif Field Independence memberi pengaruh yang berbeda terhadap hasil belajar dibanding dengan gaya kognitif Field Dependence dan strategi pembelajaran SwaAtur dan Discovery learning

Data hasil belajar seperti yang ada pada tabel 5 memperlihatkan bahwa nilai rata-rata kelompok siswa yang memiliki gaya kognitif berbeda (yaitu Field Dependence dan Field Independence) berbeda secara signifikan. Tetapi uji perbedaan nilai rerata artar sel interaksi memperlihatkan bahwa hasil belajar yang diperlihatkan kelompok siswa yang memiliki gaya kognitif Field Dependence dan Field Independence dengan adanya strategi pembelajaran (Swa-Atur dan Discovery Learning) semata-mata tidak berbeda secara signifikan. strategi pembelajaran dengan gaya kognitif terhadap hasil belajar menunjukkan tidak adanya interaksi antara keduanya.

Interaksi antara strategi pembelajaran dengan gaya kognitif terhadap hasil belajar tidak ada, kemungkinan besar disebabkan belum terkontrolnya variabel tertentu seperti proses belajar dalam diri siswa (intervening variable). Dengan demikian, dapat diduga bahwa pengaruh gaya kognitif terhadap hasil belajar bukan disebabkan oleh strategi pembelajaran.

Berdasarkan pendapat tersebut, maka temuan penelitian ini memberi justifikasi terhadap teori yang mengemukakan bahwa belajar merupakan peristiwa yang kompleks, karena aktivitas belajar dipengaruhi oleh banyak faktor, baik yang bersifat internal maupun eksternal.

\section{KESIMPULAN}

Berdasarkan bahasan dan analisis yang diperoleh makan dapat disimpulakan hasil penelitian ini yaitu 1) ada perbedaan hasil belajar kimia siswa yang menggunakan strategi pembelajaran Swa-Atur dengan pembelajaran Discovery Learning, bahwa siswa yang diberi strategi pembelajaran Swa-Atur menunjukkan hasil belajar yang lebih tinggi dibandingkan dengan siswa yang diberi perlakuan dengan strategi pembelajaran Discovery Learning, 2) ada perbedaan hasil belajar kimia siswa yang memiliki gaya kognitif Field Independence dan Field Dependence. Bahwa siswa yang memiliki gaya kognitig Field Independence memiliki hasil lebih tinggi dari pada siswa yang memiliki gaya kognitif Field Dependence, 3) tidak ada interaksi antara strategi pembelajaran (SwaAtur dan Discovery Learning) dan Gaya Kognitif (Field Independence dan Field Dependence) terhadap hasil belajar kimia.

Berdasarkan hasil penelitian, berikut dikemukakan beberapa saran yang mengacu pada upaya penggunaan strategi pembelajaran khususnya pembelajaran Swa-Atur: (1) Disarankan kepada guru-guru bidang studi kimia secara khusus dapat memperhatikan strategi pembelajaran SwaAtur sebagai salah satu pengembangan dalam proses pembelajarannya. (2) Dalam proses 
pembelajaran guru selalu memperhatikan karakteristik siswa tersebut, yang dalam penelitian ini difokuskan pada karakteristik siswa gaya kognitifnya (Field Independence dan Field Dependence). (3) Untuk menunjang keberhasilan strategi belajar yang maksimal disarankan kepada guru dapat memilih metode atau pendekatan pembelajaran yang sesuai dengan karkteristik kelas, karakteristik siswa, dan karakteristik materi pembelajarannya.

\section{DAFTAR PUSTAKA}

Alma, Buchari., dkk. (2010). Guru Profesional Menguasai Metode dan Terampil Mengajar. Bandung: Penerbit Alfabeta.

Anastasi, A. \& Urbina, S. 1997. International Edition Seventh Edition Psychologycal Testing. New Jersey: Prentice Hall. Pp.444.

Arabzadeh, M., Kadivar, P., \& Dlavar, A. (2012). The Effects of Teaching Self-Regulated Learning Strategyon Students'Academic Delay of Gratification. Interdisciplinary Journal Of Contemporary Research In Busines. Vol. 4 No. 12, pp. 580-587.

Arends, R. 2008. Learning to Teach. Yogyakarta: Pustaka Pelajar.

Chatzistamatiou, M., \& Dermitzak, I. (2013). Teaching Mathematics With SelfRegulation and for Self-Regulation: Teachers' Reports. Hellenic Journal of Psychology. Vol. 10, pp. 253-274.

Ellis, J. (2008). Psikologi Pendidikan Membantu Siswa Tumbuh dan Berkembang (Jilid 2). Jakarta: Erlangga.

Keefe, J.W. (1987). Learning Style Theory and Practice.Virginia: National Association of Secondary School Principals. p.17.

Kementrian Pendidikan dan Kebudayaan. (2014). Modul Pelatihan Implementasi Kurikulum 2013 SMP Bahasa Inggris. Jakarta: Badan Pengembangan
Sumberdaya Manusia Pendidikan dan Kebudayaan dan Penjaminan Mutu Pendidikan Kementrian Pendidikan dan Kebudayaan.

Mezei, G. (2008). Motivation And SelfRegulated Learning: A Case Study of A Pre-Intermediate and An UpperIntermediate Adult Student. Wopalp. Vol. 2, pp. 79-104.

Nanang, H., dan Suhada, C. (2009). Konsep Strategi Pembelajaran. Bandung: Refika Aditama.

Riding, R., \& Rayner, S. (1998). Cognitive Styles and Learning Strategies Understanding Style Differences in Learning and Behaviour, (London: David Fulton Publishers), p. 8.

Santrock, J. W. (2010). Psikologi Pendidikan (Edisi Kedua). Jakarta: Kencana.

Schunk, D. H. (2005). Self-regulated learning: The educational legacy of Paul $R$. Pintrich. Educational Psychologist 40, 85-94.

Slameto. (2010). Belajar \& Faktor Yang Mempengaruhi. Jakarta: PT. Rineka Cipta.

Suprijono, Agus. (2010). Cooperative Learning. Yogyakarta: Pustaka Pelajar.

Suryosubroto, B. (2009). Proses Belajar Mengajar di Sekolah. Jakarta: Rineka Cipta.

Woolfolk, A.E. (1993). Educational Psychology. London: Allyn and Bacon, p.129

Zimmerman, J. (1989). A Social Cognitive Viewof Self-Regulated Academic Learning. Journal of Educational Psychology. Vol. 81 No. 3, pp. 329-33.

Zumbrunn, S., Tadlock, J., \& Danielle, E. R. (2011). Encouraging Self-Regulated Learning in the Classroom: A Review of the Literature. Metropolitan Educational Research Consortium (MERC). Virginia: Virginia Commonwealth University. 